\title{
PERAN KOMUNIKASI DALAM KELEMBAGAAN PETANI PADA PENGEMBANGAN KAKAO DI KABUPATEN KOLAKA TIMUR
}

\author{
Putu Arimbawa $^{\left.1^{*}\right)}$, Kliwon Hidayat ${ }^{2)}$, Edi Dwi Cahyono ${ }^{2)}$, Yayuk Yuliati ${ }^{2)}$, L. Daud ${ }^{1)}$ \\ ${ }^{1}$ Jurusan Penyuluhan Pertanian Fakultas Pertanian Universitas Halu Oleo; \\ 2Jurusan Sosial Ekonomi Pertanian Fakultas Pertanian Universitas Brawijaya \\ *Corresponding author : ariembawa_kdi@yahoo.com
}

To cite this article:

Arimbawa, P., Hidayat, K., Cahyono, E., Yuliati, Y., \& Daud, L. (2020). Peran Komunikasi dalam Kelembagaan Petani pada Pengembangan Kakao di Kabupaten Kolaka Timur. Jurnal Ilmiah Membangun Desa dan Pertanian, 5(1), 8 - 18. doi:http://dx.doi.org/10.37149/jimdp.v5i1.10195

Received: January 02, 2020; Accepted: January 13, 2020; Published: January 21, 2020

\begin{abstract}
The purpose of this study is to analyze the role of communication in the information management process that occurs in farmer institutions to support cocoa development. This research is a survey research with a questionnaire as a data collection tool. The research location is in East Kolaka Regency with the target of LEMS cocoa farmers. The research location is in East Kolaka Regency with the target of LEMS cocoa farmers. Sampling as many as 267 farmers spread over 18 LEMS by proportional random sampling. Descriptive research data analysis. The results showed that the role of communication in LEMS institutions was in the medium category cocoa development. The role of communication that needs to be improved is the role in accessing information and mediating information. Information management is still dominantly sourced from explicit knowledge and does not accommodate knowledge from farmers' experience (tacit knowledge).
\end{abstract}

Keywords: the role of communication; farmer institutions; cocoa development

\section{PENDAHULUAN}

Keberlanjutan kakao rakyat menjadi tema pembicaraan setelah produktivitas kakao nasional terus mengalami penurunan dibawah potensi idealnya yang dapat mencapai 2 ton/ha. Perbandingan data produktivitas kakao snasional rata-rata 0,80 ton/ha, untuk Propinsi Sulawesi Tenggara produktivitasnya rata-rata sebesar 0,85 ton/ha (Kementerian Pertanian R.I. 2018), di Kabupaten Kolaka Timur, produktivitasnya baru mencapai 0,63 ton per hektar (Dinas Pertanian Kolaka Timur, 2018) dan hasil survai (tahun 2019) justru jauh lebih rendah yaitu 0,3 ton/ha. Tanaman sudah tua, produktivitas rendah, kurangnya bibit berkualitas dan praktek pertanian yang kurang baik adalah beberapa kelemahan dari pengembangan kakao di Sulawesi Tenggara (Geo \& Saediman, 2019). Produktivitas dan mutu kakao rendah mengancam keberlanjutannya (Widayanto, 2013). Upaya yang dilakukan untuk mengatasi rendahnya produksi dan percepatan pengembangan kakao adalah melakukan revitalisasi perkebunan kakao melalui perluasan, peremajaan dan rehabilitasi tanaman. Mengingat tanaman kakao telah memasuki masa yang tidak produktif (umur tanaman sudah lebih dari 20 tahun) maka peremajaan (replanting) menjadi program yang dipilih pemerintah untuk diterapkan oleh petani. Namun, program tersebut mendapat persepsi yang beragam di tingkat petani. Sebagian petani menganggap kakao petani sudah saatnya direplanting dan sebagian lagi belum perlu direplanting.

Berbagai persepsi petani terhadap teknologi pertanian terkait pendekatan dilakukan yang cenderung terpusat (top down) dengan pola komunikasi linier yang tidak partisipatif sehingga kecenderungan petani hanya sebagai objek pembangunan (Leeuwis, 2009). Replanting kakao di Kabupaten Kolaka Timur dilakukan oleh pemerintah dengan pemberian bantuan benih/bibit dan pupuk kepada petani. Nonci, (2017) menyatakan pendekatan pembangunan yang sentralistik cenderung berfokus pada transfer teknologi untuk peningkatan produksi (product oriented) bukan difokuskan kepada petani atau manusia (people oriented). Proses pembangunan yang sentralistik 
menyebabkan petani bersifat pasif, kurang kreatif dan kurang inovatif serta cenderung tergantung pada bantuan pemerintah (Rostin et al. 2016).

Pengembangan kakao melalui kelembagaan petani belum sesuai dengan fungsi dan peran kelembagaan yang seharusnya. Keterlibatan kelembagaan petani hanya berperan sebagai "tukang pos" yaitu menerima dan mendistribusikan bantuan kepada petani. Pemerintah melakukan komunikasi dengan kelembagaan petani dalam hal koordinasi pelaksanaan kegiatan yang sudah direncanakan tidak untuk membangun kesepahaman bersama (mutual understanding). Kesepahaman bersama dapat terjadi jika ada sharing informasi antara berbagai aktor dalam pembangunan (Figueroa et al., 2002). Tidak terjadinya sharing informasi antar aktor menyebabkan banyak program pemerintah yang tujuannya untuk pemberdayaan masyarakat kurang berhasil, karena kurang bermanfaat bagi pengguna (user). Agunga et al, (2016) menyatakan bahwa dalam strategi penyuluhan komunikasi pembangunan diperlukan komunikasi antar aktor baik antar petani dan antar kelembagaan petani. Shinta dan Cahyono (2007) menemukan bahwa kebijakan pembangunan perlu memperhatikan sistem kelembagaan sosial dalam pengelolaan sumberdaya lokal yang telah terbukti efektif. Peran komunikasi kelembagaan/kelompok sebagai media informasi dapat mempengaruhi adopsi inovasi oleh petani (Inggrida et al., 2017; Adawiyah et al. 2017). Disamping itu, dengan berperannya kelembagaan petani sebagai media komunikasi informasi membantu peran penyuluh dalam melakukan upaya penyuluhan yang partisipatif yang selama ini kurang dapat dilakukan karena kurang adanya organisasi pendukung (Cahyono, 2014). Informasi yang diperoleh dari hasil diskusi antar petani, penyuluh dan lembaga terkait dapat diolah dan digunakan oleh pemerintah sebagai dasar untuk membuat kebijakkan/program pengembangan kakao dalam mendukung peningkatan produktivitas dan keberlanjutan usahatani kakao. Tujuan penelitian ini adalah menganalisis peran komunikasi dalam proses pengelolaan informasi yang terjadi dalam kelembagaan petani untuk mendukung pengembangan kakao di Kabupaten Kolaka Timur

\section{MATERI DAN METODE}

Penelitian ini merupakan penelitian survai. Tempat penelitian di Kabupaten Kolaka Timur, Propinsi Sulawesi Tenggara pada 18 desa yang telah memiliki LEMS yang tersebar pada empat kecamatan. Ke-18 desa/LEMS dipilih karena merupakan desa/LEMS yang mayoritas penduduk/anggotanya mengusahakan kakao sebagai sumber penghasilan utama. Penelitian dilakukan selama delapan bulan yaitu bulan April sampai Nopember 2019. Objek penelitian adalah petani kakao anggota LEMS. Jumlah sampel sebanyak 267 petani dari 1.532 petani anggota LEMS sebagai populasi yang dipilih secara acak proporsional (proportional random sampling) dari setiap LEMS dengan pengurus inti LEMS (ketua, sekretaris dan bendahara) secara sengaja diambil sebagai sampel. Variabel peran komunikasi dalam kelembagaan petani diukur dengan lima indikator, yaitu; akses informasi, mediasi informasi, metode komunikasi informasi, efektivitas komunikasi informasi dan insentif informasi. Metode pengumpulan data dengan wawancara kepada anggota LEMS terpilih dengan menggunakan kuesioner yang telah terlebih dahulu dilakukan uji validitas dan reliabilitas. Pengumpulan data juga dilakukan menggunakan teknik diskusi terfokus (FGD). Analisis data menggunakan analisis deskriptif.

\section{HASIL DAN PEMBAHASAN}

\section{Karakteristik Petani}

Karakteristik petani merupakan sifat-sifat atau ciri-ciri yang melekat pada diri seseorang yang berhubungan dengan kehidupan dan lingkungannya. Karakteristik seseorang/individu mempengaruhi interaksi seseorang dengan lingkungannya dalam memenuhi kebutuhan hidupnya. Karakteristik petani kakao yang diteliti meliputi aspek umur, tingkat pendidikan formal, intensitas pendidikan non formal, pengalaman berusahatani, dan luas lahan garapan.

Hasil penelitian menunjukkan umur petani kakao dominan berkisar antara 35 - 44 tahun $(56,6$ persen) dengan kisaran umur petani responden termuda umur 25 tahun dan tertua umur 71 tahun. Jika dilihat dari rataaan umur petani kakao di Kolaka Timur yaitu 41,82 tahun. Berdasarkan produktivitas umur petani (15-54 tahun) sebagian besar petani kakao (97,4 persen) tergolong umur produkti, sedangkan kategorisasi produktivitas umur menurut Rusli (2012) bahwa seseorang dikatakan masih produktif dalam bekerja pada rentang umur 15-65 tahun. Petani yang lebih tua mengalami kesulitan untuk menerima dan menerapkan teknologi baru dibandingkan yang masih muda karena masih terpengaruh dengan cara-cara yang lama sehingga lebih lambat dalam mengambil keputusan untuk menerima inovasi (Fatchiya, 2010, Murphy et al., 2011; Burton et al., 2014). Hal ini dikuatkan oleh Davis et al., (2009) yang mengemukakan bahwa petani yang berumur 
muda lebih mudah terpengaruh proses pengelolahan lahan dan memiliki perencanaan yang baik, serta cenderung melakukan investasi bisnis lebih banyak, dibandingkan dengan petani yang lebih tua. Namun demikian, petani yang lebih tua biasanya memiliki asset seperti lahan usahatani lebih luas dibandingkan dengan petani yang lebih muda, akan tetapi dalam hal adopsi teknologi masih rendah (Alexopoulos et al., 2010 dalam Managanta, 2018). Oleh karena itu, perlu keberpihakan program kepada petani muda dalam bentuk pemberian insentif agar petani muda bergairah untuk terus menekuni sektor pertanian (Susilowati, 2016).

Tingkat Pendidikan formal menunjukkan bahwa dominan petani kakao (34,5 persen) berpendidikan tamat SD, 30,3 persen telah mengenyam pendidikan SMP dan sampai pada perguruan tinggi (PT) baik diploma maupun sarjana, namun masih ada petani yang belum pernah mengenyam pendidikan formal. Dilihat dari tingkat pendidikan formal tersebut, menunjukkan bahwa tingkat pendidikan petani kakao di Kabupaten Kolaka Timur kategori rendah atau dengan rataan waktu pendidikan formal yang pernah ditempuh petani kakao selama 8,56 tahun (SMP). Tinggi rendahnya pendidikan seseorang mempengaruhi cara berpikir dan cara bertindak secara lebih rasional untuk menerima maupun menolak inovasi teknologi yang datang pada dirinya (Ruhimat (2015) dalam Prawiranegara, 2016). Rendahnya pendidikan formal yang dimiliki petani kakao di Kabupaten Kolaka Timur dapat diatasi melalui kegiatan-kegiatan pelatihan/kursus dan belajar bersama secara rutin kepada petani. Rendahnya pendidikan formal petani dapat diantisipasi melalui pemberian pelatihan sebagai bentuk pendidikan nonformal bagi petani. Berdasarkan hasil penelitian intensitas pendidikan nonformal sebagian besar petani (39,33 persen) pernah mengikuti penyuluhan dan pelatihan tiga kali dalam dua tahun terakhir. Dilihat dari rataan intensitas pendidikan nonformal yang pernah diikuti petani kakao sebesar 2,74 kali mengindikasikan bahwa petani kakao masih kurang mendapatkan pendidikan nonformal secara merata dalam kegiatan pengembangan kakao. Pendidikan nonformal yang sering diikuti petani seperti penyuluhan pertanian, pelatihan dari penyuluh maupun dari dinas pertanian/perkebunan melalui kelembagaan LEMS baik tingkat kabupaten maupun provinsi. Pendidikan nonformal seperti kegiatan penyuluhan, pelatihan, penataran, dan bentuk keterampilan teknis lainnya bertujuan untuk meningkatkan kecerdasan dan keterampilan seseorang atau petani (Suprijanto, 2012; Supriatna (Prawiranegara (2014)). Fakta tersebut didukung oleh Rogers (2003) yang menyatakan bahwa pendidikan berpengaruh pada penerimaan petani terhadap inovasi.

Berdasarkan pengalaman petani dalam berusahatani kakao, hasil penelitian menunjukkan bahwa sebagian besar (47,9 persen) petani kakao telah cukup berpengalaman dalam berusahatani kakao dengan lama pengalaman 11-15 tahun. Adapun rentang pengalaman petani dalam berusahatani kakao di empat kecamatan di Kolaka Timur antara 5-35 tahun. Artinya bahwa, petani kakao di Kabupaten Kolaka Timur telah memiliki pengalaman yang cukup dalam berusahatani kakao. Pengalaman yang cukup lama tersebut akan memberikan pengetahuan dan keterampilan bagi petani dalam melakukan mengembangkan kakao dengan lebih baik. Hal ini didukung oleh hasil penelitian Fatchiya (2010) bahwa faktor karakteristik internal seperti pengalaman kerja sebagai salah satu faktor yang dapat mempengaruhi kapasitas inovasi seseorang. Kondisi tersebut menunjukkan bahwa dengan pengalaman, petani dapat menilai baik buruknya teknologi inovasi yang ada. Petani akan berhati-hati dalam penerapan teknologi terhadap resiko kegagalan (Fausayana et al, 2017). Untuk itu, setiap kebijakan pemerintah perlu memperhatikan sumber daya lokal, kelembagaan sosial dan budaya masyarakat yang terbukti efektif (Shinta dan Cahyono, 2007) memperlancar perlaksanaan program. Disamping pengalaman petani, luas lahan garapan merupakan karakteristik petani yang perlu diketahui dalam mendukung pengembangan kakao. Hasil penelitian menunjukkan bahwa sebagian besar petani $(49,1$ persen) memiliki luas lahan garapan kakao antara 2-2,9 hektar. Adapun kisaran luas lahan kakao petani responden antara 0,5-8 ha, artinya bahwa, petani kakao di Kolaka Timur ada yang memiliki lahan sempit $(0,5 \mathrm{ha})$ dan ada yang memiliki lahan kakao sangat luas (sampai 8 ha). Namun jika dilihat dari rataan luas lahan garapan sebesar 2,35 hektar bisa dikategorikan petani kakao di Kolaka Timur memiliki luas lahan yang cukup luas yang keseluruhannya merupakan lahan milik. Kondisi tersebut menunjukkan bahwa, dari segi luas lahan petani kakao di Kabupaten Kolaka Timur tidak mengalami permasalahan terkait dengan introduksi teknologi peremajaan tanaman kakao dengan sambung pucuk yang sedang digalakkan oleh pemerintah karena adanya lahan yang memadai dimiliki oleh petani. Karakteristik individu berhubungan dengan tingkah laku seseorang dalam semua aspek kehidupan dan lingkungannya (Rogers \& Shoemaker, 1987). Untuk itu, didalam melakukan pengembangan kakao perlu memperhatikan karaktertistik petani, sehingga pendekatan yang dilakukan sesuai dengan kondisi dan kebutuhan petani sebagai pelaku dan penerima manfaat kegiatan.

\section{Peran Komunikasi dalam Kelembagaan Petani}


Peran komunikasi dalam kelembagaan merupakan konsep yang mengambarkan tentang bagaimana proses pertukaran pesan (message prosessing) yang terjadi antar pelaku komunikasi dalam suatu kelembagaaan untuk mencapai kesepahaman pesan yang dikomunikasikan dalam suatu proses belajar. Kelembagaan petani sebagai wadah belajar petani dapat melakukan komunikasi informasi melalui sharing informasi/pengetahuan antara petani dengan petani, petani dengan lembaga tani dan lembaga tani dengan kelembagaan tani lainnya. Peran komunikasi dalam kelembagaan dapat mendorong terjadinya komunikasi stakeholder untuk berbagai isu pembangunan. Hasil penelitian peran komunikasi dalam kelembagaan petani (Tabel 1) menunjukkan kesemua peran sebagian besar berada pada kategori sedang.

Tabel 1. Peran komunikasi dalam kelembagaan petani

\begin{tabular}{lcccccc}
\hline \multirow{2}{*}{ Aspek } & \multicolumn{7}{c}{ Kategori (\%) } & \multirow{2}{*}{ Rataan } \\
\cline { 2 - 6 } & 1 & 2 & 3 & 4 & 5 & \\
\hline Akses informasi & 2,2 & 35,2 & 36,7 & 22,8 & 3,0 & 2,89 \\
Mediasi informasi & 1,1 & 35,2 & 34,5 & 24,7 & 4,5 & 2,96 \\
Metode komunikasi informasi & 0,4 & 21,3 & 49,4 & 24,3 & 4,5 & 3,11 \\
Efektivitas komunikasi informasi & 0,4 & 22,8 & 47,6 & 25,8 & 3,4 & 3,09 \\
Insentif informasi & 0,4 & 24,7 & 47,6 & 22,8 & 4,5 & 3,06 \\
\hline & \multicolumn{7}{l}{ Total Rataan } & & & & 3,02 \\
\hline
\end{tabular}

Ket: $1=$ sangat rendah, 2=rendah, 3=sedang, 4= tinggi, dan 5=sangat tinggi

Sumber: Analisis data primer, 2019

a. Akses Informasi

Peran komunikasi petani dalam LEMS terhadap akses informasi (Tabel 1) sebagian besar $(36,7 \%)$ kategori sedang. Peran komunikasi dalam akses informasi dilihat dari: (1) peran dalam pencarian informasi terhadap sumber informasi (58,95\%), (2) kualitas dan kebaharuan informasi yang diperoleh (57,6\%), (3) pengolahan informasi $(57,45 \%)$, dan (4) penyebaran informasi $(60,67 \%)$ (Gb. 1). Gambar 1 menunjukkan bahwa dari empat kriteria peran komunikasi dalam akses informasi peran dalam penyebaran informasi sudah dilakukan cukup baik sedangkan peran dalam pencarian informasi, kualitas/kebaharuan informasi yang diperoleh dan pengolahan informasi masih kurang baik. Penyebaran informasi yang dilakukan petani maupun LEMS dilakukan setiap ada informasi yang diperoleh melalui pertemuan LEMS maupun dari peteni ke petani lainnya baik langsung maupun dengan media elektronik seperti handphone.

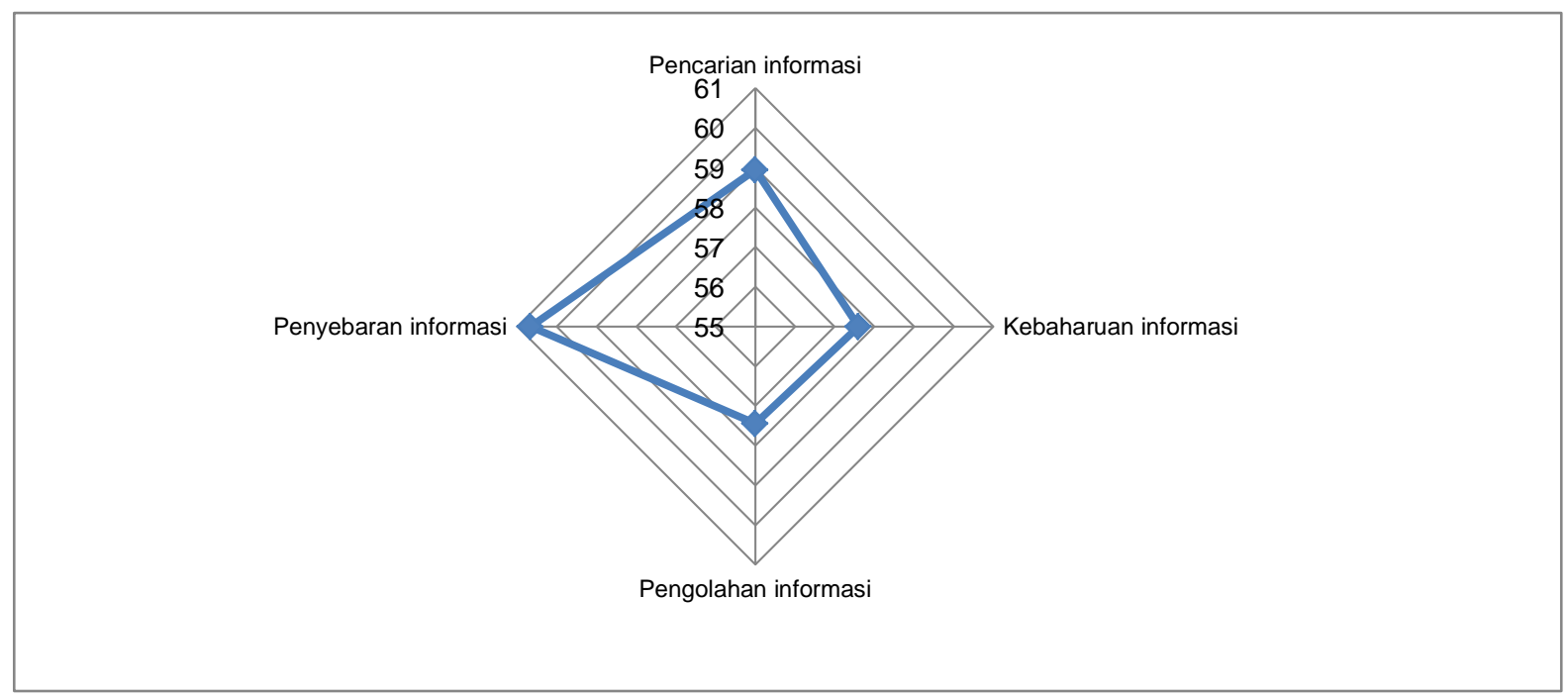

Gambar 1. Peran komunikasi dalam akses informasi

Proses pencarian informasi oleh petani dilakukan sesama petani dan pengurus LEMS maupun penyuluh. Petani jarang sekali melakukan pencarian informasi dengan menggunakan media massa (baik cetak maupun elektronik dan internet) lebih banyak kepada melalui intranet yaitu diskusi sesama petani, pengurus LEMS maupun penyuluh, sedangkan pengurus LEMS pencarian informasinya melalui penyuluh dan pemerintah (dinas perkebunan) sebagai sumber informasi utama. Sebagian besar petani merasakan kurang merasakan adanya informasi baru terkait dengan pengembangkan kakao. Hampir semua informasi yang diperoleh mereka telah ketahui termasuk 
informasi tentang bibit kakao sambung pucuk. Kondisi tersebut dikarenakan petani maupun pengurus LEMS jarang melakukan akses informasi dari media massa seperti televisi maupun internet sebagai sumber informasi terbaru. Oleh karena itu, sumber informasi yang hanya bersumber dari satu sumber memungkinkan pengelolaan informasi oleh petani dalam suatu kelembagaan petani masih rendah. Secara umum peran komunikasi petani dalam akses informasi masih rendah. Peran petani dalam akses informasi masih rendah merupakan masalah yang fundamental yang dihadapi petani kecil (Cahyono, 2014; Agunga, Cahyono, Buck, \& Scheer, 2016).

\section{b. Mediasi informasi}

Peran komunikasi dalam LEMS yang dirasakan petani sebagai mediasi informasi (Tabel 1) sebagian besar $(54,5 \%)$ kategori sedang. Peran komunikasi dalam mediasi informasi dilihat dari: (1) peran dalam melakukan diskusi sesama petani setiap ada permasalahan $(65,84 \%)$, (2) melakukan diskusi setiap pertemuan LEMS (57,60\%), dan (3) LEMS memfasilitasi permasalahan yang dihadapi petani $(54,98 \%)$. Peran dalam mediasi informasi pada tiga kriteria yang diteliti menunjukkan peran dalam melakukan diskusi informasi sesama petani sudah cukup baik, namun peran dalam melakukan diskusi petani dalam kelembagaan LEMS dan memfasilitasi informasi bagi petani masih kurang dilakukan (Gambar 2).

Mediasi informasi terkait dengan pengembangan kakao biasa dilakukan petani dengan petani lainnya baik kegiatan informal maupun dalam kegiatan formal seperti pertemuan kelompok petani atau LEMS. Kegiatan diskusi sebagian besar dilakukan secara informal yaitu saat petani bertemu di kebun maupun saat waktu luang berkumpul di rumah salah seorang petani untuk membicarakan masalah yang dihadapi dalam pengembangan kakao. Pertemuan dan diskusi petani dalam kegiatan LEMS masih kurang dilakukan secara kontinu. Petani lebih banyak berdiskusi dengan petani lainnya yang dinilai lebih maju dalam pengembangan kakao. Fasilitasi yang dilakukan LEMS hanya dalam bentuk pemberian informasi proses penyaluran bibit kakao kepada petani.

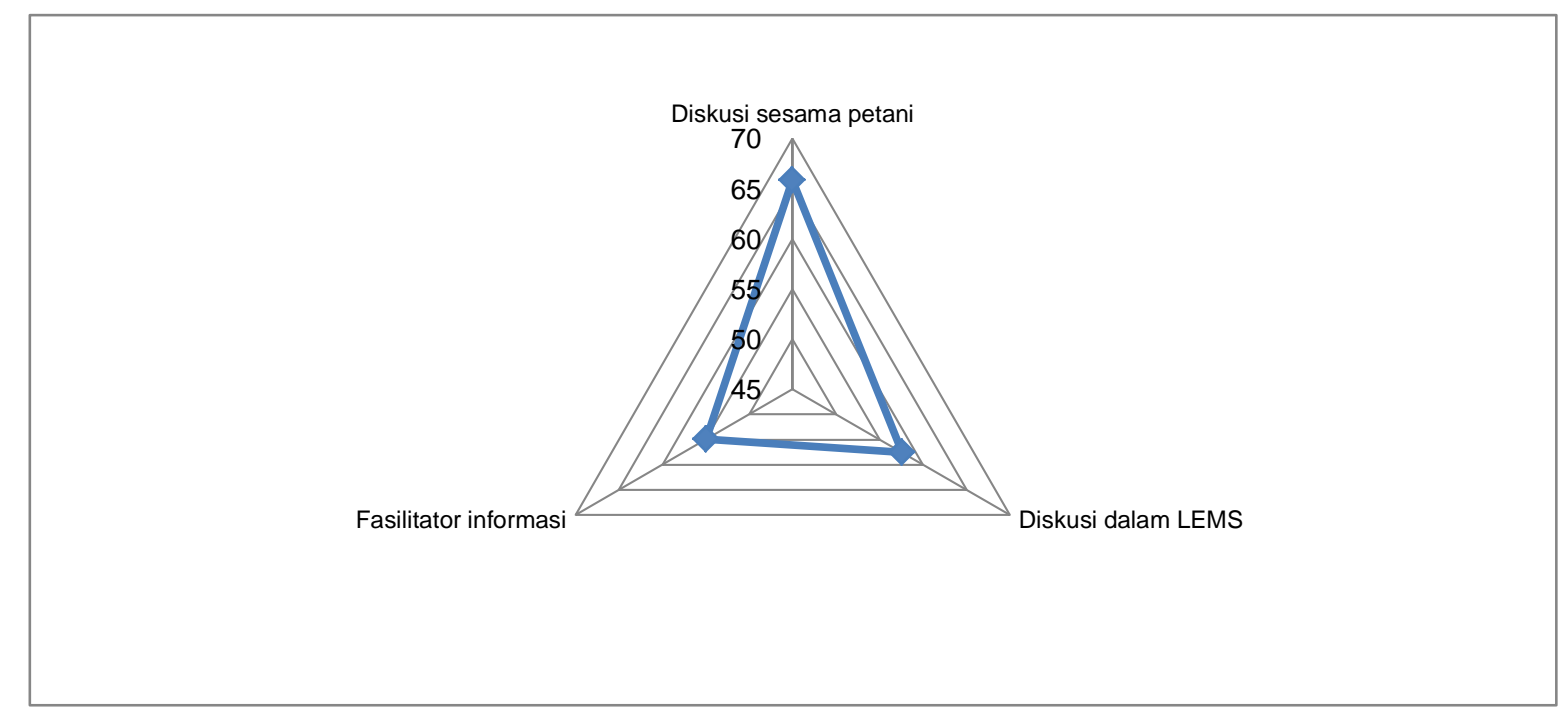

Gambar 2. Peran komunikasi dalam mediasi informasi

Fasilitasi oleh LEMS dilakukan saat ada program dari pemerintah yaitu melalui dinas perkebunan tentang teknis pelaksanaan di lapangan. Proses fasilitasi melibatkan petani anggota melalui pertemuan LEMS. Namun demikian, pertemuan yang dilakukan LEMS, petani kurang aktif mengikutinya. Rendahnya kelembagaan petani (LEMS) berperan dalam mediasi informasi berhubungan dengan perilaku petani (Lin \& Peng, 2010). Petani akan berperilaku positif terhadap kegiatan kelompok jika petani merasakan kelompok tersebut memberikan daya tarik bagi petani. Oleh karena itu, peran mediasi informasi dalam kelembagaan petani dipengaruhi oleh penilaian masingmasing anggota kelompok (Gigone \& Hastie, 1993).

\section{c. Metode komunikasi informasi}

Metode komunikasi informasi merupakan peran komunikasi yang dilakukan dalam suatu kelembagaan petani dalam mendukung pengembangan kakao di Kabupaten Kolaka Timur. Peran komunikasi dalam penggunaan metode komunikasi informasi sebagian besar (Tabel 1) berada pada kategori sedang (49,4\%). Penggunaan metode komunikasi informasi meliputi; (1) pelatihan 
pembibitan (54\%), pengolahan lahan $(62,1 \%)$, penanaman $(66,89 \%)$, pemupukan tanaman $(68,84 \%)$, pengendalian hama dan penyakit $(67,71 \%)$, fermentasi biji kakao (56,55\%); dan (2) melakukan kunjungan/anjangsana ke kebun petani kakao yang berhasil (54,91\%) (Gambar 3).

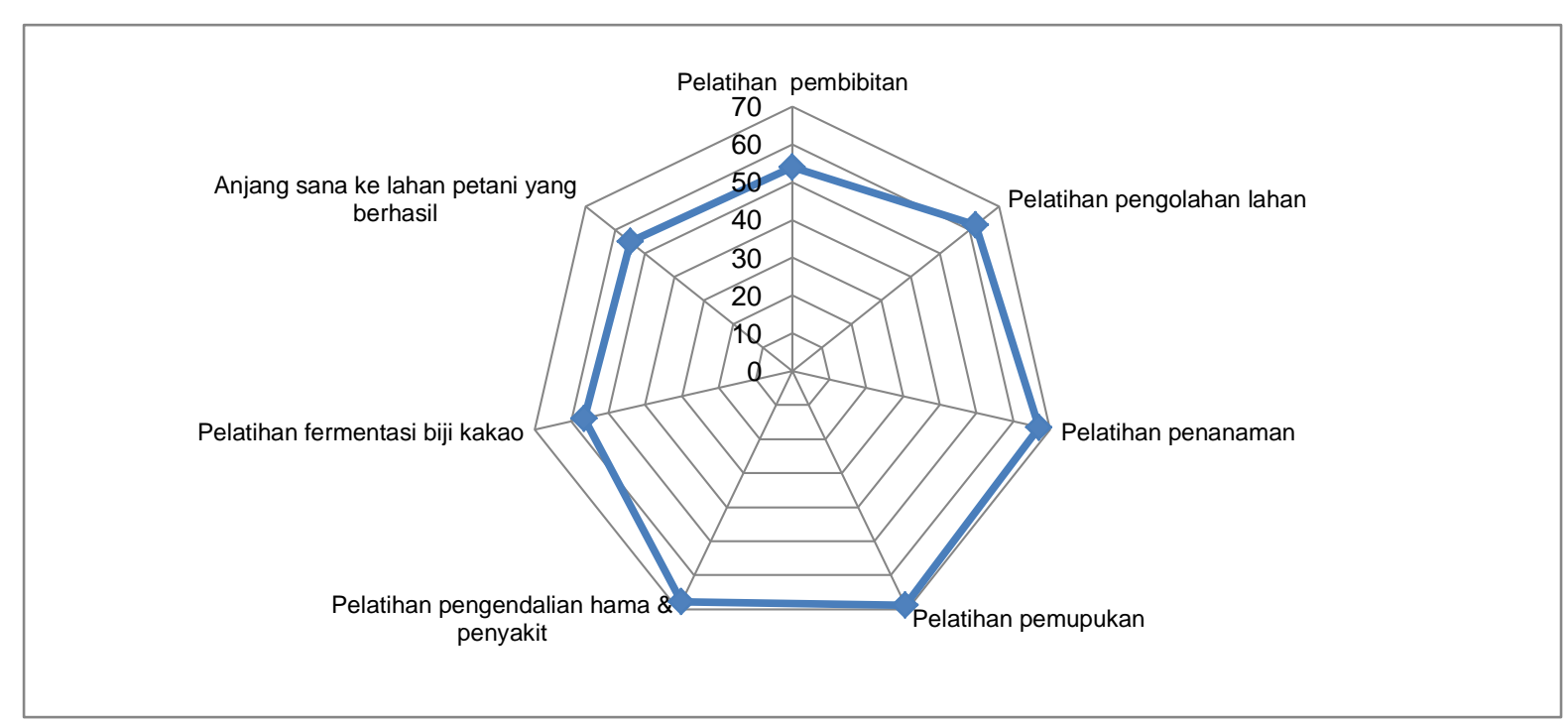

Gambar 3. Peran komunikasi dalam metode komunikasi informasi

Gambar 3 menunjukkan bahwa pelatihan yang paling sering diikuti petani kakao meliputi pelatihan tentang penanaman kakao, pemupukan dan pengendalian hama dan penyakit. Selanjutnya pelatihan tentang pengolahan lahan, fermentasi dan pembibitan adalah pelatihan yang yang kadang diikuti oleh petani kakao. Diantara pelatihan dalam menunjang pengembangan kakao, pelatihan tentang cara pembibitan tanaman kakao masih sangat kurang diikuti petani. Pelatihan adalah salah satu metode yang sering digunakan dan diikuti petani kakao anggota LEMS dalam menunjang pengembangan kakao di Kabupaten Kolaka Timur sedangkan metode atau pendekatan anjang sana ke kebun petani yang dianggap berhasil adalah suatu metode yang sesekali digunakan dalam transfer teknologi kepada petani kakao anggota LEMS. Program pengembangan kakao di Kabupaten Kolaka Timur perlu didukung oleh kesiapan sumber daya manusia dan sumber daya lahan. Oleh karena itu, pemilihan metode dalam mendukung pengembangan kakao menjadi sangat penting guna mensukseskan program tersebut. Pemberian pelatihan dan kunjungan ke kebun kakao yang berhasil kepada petani memungkinkan petani kakao dapat belajar sesama petani dan para ahli dan melihat langsung penerapan teknologi peremajaan tanaman yang sudah berhasil dari pengetahuan tacit (pengalaman petani) ke pengetahuan explicit (yang sudah terdokumentasikan) yang disebarkan para ahli (penyuluh) untuk terapkan (Nawawi, 2012) oleh petani pada lahan usahataninya. LEMS sebagai kelembagaan petani dapat berperan sebagai media pembelajaran untuk mendorong penggunaan metode komunikasi agar petani dapat berpartisiapsi secara aktif dalam setiap kegiatan kelompok (Koesoemowardani \& Sumardjo, 2008) dalam mendukung pengembangan kakao di Kolaka Timur.

\section{d. Efektivitas komunikasi informasi}

Peran komunikasi dalam kelembagaan LEMS dari segi efektivitas komunikasi informasi (Tabel 1) menunjukkan sebagian besar $(47,6 \%)$ kategori sedang. Peran komunikasi dalam kelembagaan LEMS dilihat dari efektivitas komunikasi informasi dilakukan dengan mengetahui tingkat pengetahuan dan keterampilan petani dalam: (1) pembibitan tanaman kakao $(51,91 \%)$, (2) penggunaan pupuk organik pada lahan kakao $(61,12 \%)$, (3) peremajaan tanaman kakao $(64,42 \%)$, (4) pemilihan jenis pupuk yang digunakan $(72,21 \%)$, (5) pengendalian hama dan penyakit kakao (72,06\%), dan (6) fermentasi biji kakao (47,42\%) (Gambar 4).

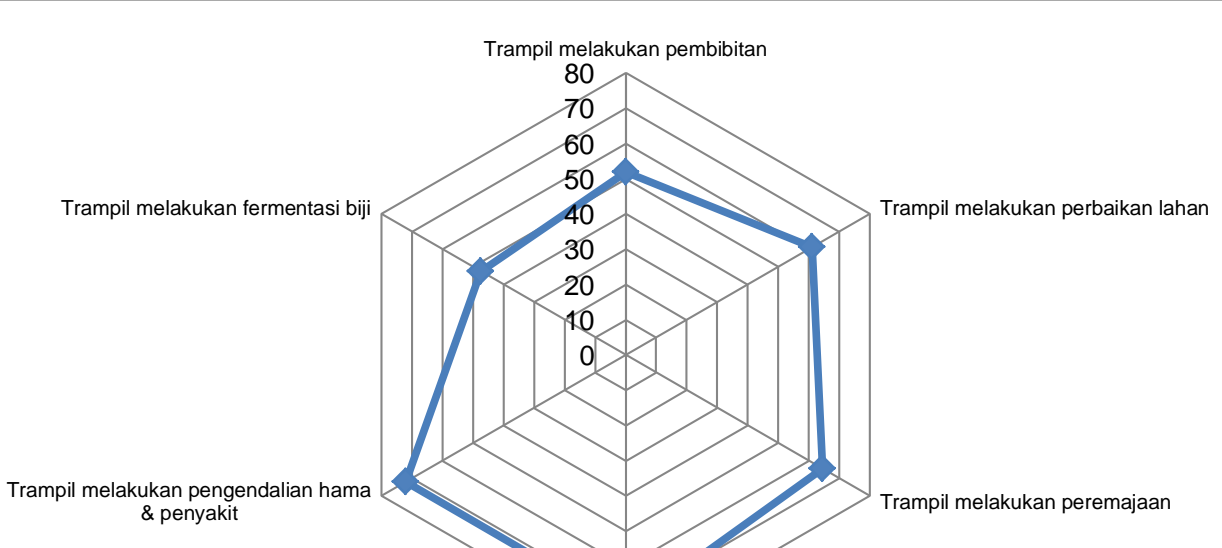


Gambar 4. Peran komunikasi dalam efektivitas komunikasi informasi

Efektivitas komunikasi informasi (Gambar 4) merupakan gambaran peran komunikasi yang dilakukan dalam kelembagaan LEMS terhadap pengetahuan dan keterampilan petani kakao menerapkan program pengembangan kakao yang telah mereka ketahui dari pelatihan diperoleh. Gambar 4 diketahui bahwa petani kakao telah memiliki ketrampilan dalam melakukan pemupukan dan pengendalian hama dan penyakit tanaman, cukup terampil dalam melakukan perbaikan lahan dan peremajaan tanaman dan masih kurang terampil dalam melakukan pembibitan dan fermentasi biji kakao. Adanya perbedaan petani dalam pengembangan kakao menunjukkan bahwa peran komunikasi dalam kelembagaan petani belum begitu efektif. Komunikasi yang efektif memungkinkan peningkatan pengetahuan dan keterampilan petani dalam menunjang pengembangan usahatani (Koesoemowardani \& Sumardjo, 2008).

e. Insentif informasi

Peran komunikasi dalam kelembagaan LEMS dalam insentif informasi (Tabel 1) menunjukkan sebagian besar $(47,6 \%)$ kategori sedang. Insentif informasi dapat dilihat dari: (1) adanya informasi bagi petani untuk mendapatkan bibit kakao $(67,34 \%)$, kemudahan mendapatkan pupuk $(61,12 \%)$, dan (3) kemudahan mendapatkan modal usaha $(53,11 \%)$ dalam mendukung pengembangan kakao (Gambar 5).

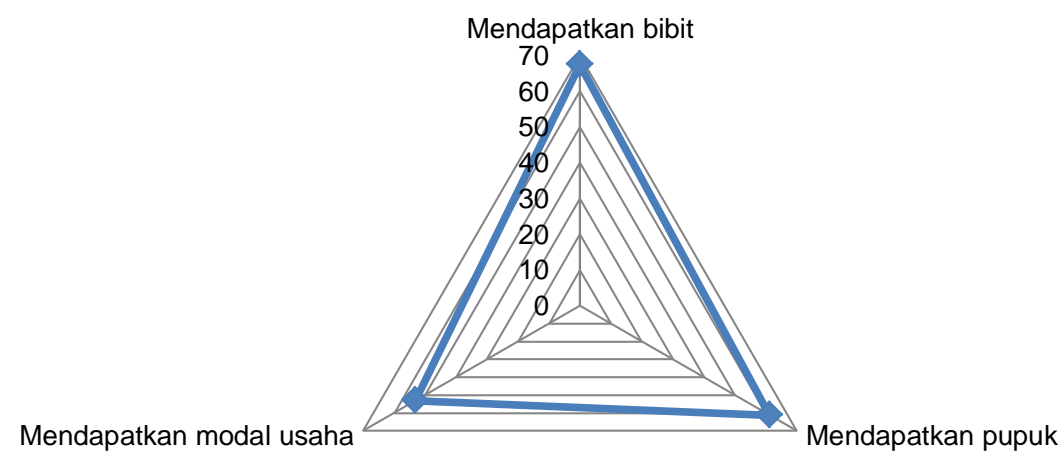

Gambar 5. Peran komunikasi dalam insentif informasi

Gambar 5 menunjukkan bahwa peran komunikasi dalam kelembagaan petani terhadap insentif informasi sudah cukup baik. Hal tersebut dapat dilihat dari tiga kriteria yang dilihat bahwa hampir semua manfaat dari program pengembangan kakao telah diketahui dan diperoleh oleh petani yaitu bibit dan pupuk, sedangkan dalam hal modal usaha masih dirasakan kurang oleh petani kakao.

Secara umum peran komunikasi dalam kelembagaan LEMS dapat dilihat dari nilai total rataan skor diperoleh nilai 3,26 (Tabel 1) menunjukkan bahwa peran komunikasi dalam pengembangan kakao berbasis kelembagaan LEMS di Kabupaten Kolaka Timur berada dalam kategori sedang. Fakta tersebut dapat dilihat dari peran kelembagaan LEMS sudah melakukan komunikasi informasi dalam pencarian, pengolahan dan penyebaran informasi ke petani, masih kurang dalam melakukan 
mediasi antar petani terhadap permasalahan replanting termasuk masalah kualitas bibit/benih yang diberikan. Metode komunikasi yang dilakukan sudah cukup baik namun masih bersifat linier yaitu informasi yang diberikan oleh ahli melalui pelatihan dan masih masih perlu tiditnkatkan anjangsana ke lokasi petani kakao yang telah berhasil sehingga komunikasi dengan mengali pengetahuan petani dengan pendekatan buttom-up dapat terjadi dalam kelembagaan LEMS. Menurut Cahyono dan Angunga (2016) proses komunikasi dalam kelembagaan petani tidaklah mudah, namun peran komunikasi menjadi sangat penting dalam sistem pengembangan pertanian. Hasil studi juga menunjukkan bahwa proses pembangunan berjalan efektif jika komunikasi antar kelompok masyarakat berjalan lancar (Inggrida et al., 2017).

Peran LEMS sebagai wadah belajar dan informasi petani masih perlu ditingkatkan. Sebagai wadah belajar kelembagaan petani dapat menerapkan metode pembelajaran sosial (social learning) melalui komunikasi inovasi secara interaktif dalam setiap permasalahan yang dihadapi petani (Leeuwis, 2009). Model komunikasi konvergensi memungkinkan LEMS sebagai media komunikasi dan pembelajaran sosial petani melalui perannya sebagai wadah diskusi untuk semua aktor dalam pengembangan kakao. Rangkuti (2010) menyatakan penerapan model komunikasi konvergensi dalam organisasi koperasi memungkinkan terjadinya sinergi kerjasama dengan pelaku ekonomi lainnya sehingga terwujud pertanian modern. Peran komunikasi dalam kelembagaan LEMS pada petani kakao yang cenderung masih rendah, memerlukan kesadaran semua aktor mau duduk bersama untuk mencapai kesepahaman bersama dalam mencari solusi pada percepatan program replanting kakao. Adanya sebagian petani cenderung masih bertindak sendiri dalam pengembangan kakao menandakan diperlukannya intervensi komunikasi yang berbeda kepada mereka baik oleh kelembagaan dan pemangku kepentingan lainnya (Leeuwis, 2009). Komunikasi berperan dalam memfasilitasi proses penyebaran ide, gagasan, teknologi kepada masyarakat. Dalam kontek kelembagaan petani, komunikasi dapat berperan sebagai penyampaian informasi, maupun pertukaran informasi antar sesama petani dan lembaga agar tercapai saling kesepahaman bersama (Figueroa et al., 2002). Kelembagaan petani sebagai wadah petani dituntut lebih adaptif terhadap perkembangan informasi diera perkembangan teknologi informasi dan komunikasi saat ini. Keberadaan kelembagaan dapat mengatasi adanya ketimpangan atau kesenjangan yang terjadi diantara petani akibat perbedaan akses informasi dan komunikasi yang terjadi di masyarakat desa. Menurut McCroskey adanya proses bersama dalam pengelolaan informasi dalam suatu kelembagaan petani pertanda bahwa kelembagaan telah berperan sebagai knowledge sharing yaitu proses komunikasi pembelajaran melalui proses dialog, pertukaran ide, gagasan, pengetahuan untuk mencapai kesepahaman bersama (Iriantara, 2014).

\section{Proses Pengelolaan informasi dalam Kelembagaan Petani}

Beberapa peran komunikasi dalam kelembagaan LEMS telah teridentifikasi secara kuantitatif yang menunjukkan perannya masih perlu ditingkatkan lagi. Fakta tersebut dapat dijelaskan dari hasil wawancara dengan pengurus LEMS yaitu, terdapat beberapa peran LEMS dalam proses pengelolaan informasi inovasi terkait dengan pengembangan kakao di Kabupaten Kolaka Timur yang belum dilaksanakan dengan baik. Proses pengelolaan informasi yang dilakukan LEMS dapat dilihat berdasarkan konsep manajemen pengetahuan (knowledge management) (Jane, 2011). Penggunaan konsep knowledge management dalam LEMS adalah untuk mengetahui penggunaan pengetahuan yang bersifat pemikiran atau terbatinkan (tacit knowledge) dan pengetetahuan yang sudah terekam atau terdokumentasikan (explicit knowledge) dalam pengembangan kakao. Kolaborasi dua pengetahuan ini menjadi sangat penting didalam percepatan pembangunan pertanian khususnya dalam pengembangan kakao berkelanjutan. Tacit knowledge dapat berasal dari pengalaman petani selama berusahatani kakao yang masih sulit untuk ditransfer pengetahuannya kepada orang lain, sedangkan explicit knowledge merupakan pengetahuan yang sudah terdokumentasikan yang berasal dari hasil-hasil penelitian dan para pakar yang mudah untuk ditransfer kepada orang lain (Nawawi, 2012).

Proses pengelolaan informasi atau pengetahuan dengan penerapan konsep 3D yaitu discover, develop dan disseminate. Penerapan konsep 3D dapat dilihat dari petani dan kelembagaan LEMS mengelola informasi yang diperoleh. LEMS dan petani mengali informasi/inovasi tentang kakao bersumber dari dinas pertanian/perkebunan, penyuluh pertanian, LSM/NGO dan ahli lainnya serta dari petani yang berhasil. Informasi yang diperoleh (discover) kemudian dipelajari dan dipilah mana yang sesuai dengan kebutuhan petani untuk disederhanakan agar dapat dipraktekkan di lapang. Informasi atau inovasi yang sudah diperoleh dan dipilah tersebut selanjutnya diuji coba oleh pengurus LEMS dalam luasan skala kecil di lahan milik pengurus (develop). Ide baru/inovasi yang sudah diujikan tersebut disebarkan kepada petani kakao lainnya (disseminate). Pada tahap ini biasanya akan terjadi proses dialog/diskusi antar petani untuk merespon inovasi yang direkomendasikan oleh 
LEMS kepada petani (proses internalisasi). Setelah itu berdasarkan penilaian petani menguntungkan petani akan menerapkannya di lahan miliknya dan selanjutnya informasi yang sudah diterapkan tersebut dapat menjadi informasi baru lagi bagi petani kakao masa berikutnya (Gambar 6).

Proses pengelolaan informasi dalam LEMS (lihat Gambar 6) belum sepenuhnya dilakukan dalam kelembagaan LEMS di Kolaka Timur sesuai dengan konsep manajemen pengetahuan. Proses yang masih perlu ditingkatkan adalah mulai dari proses pencarian informasi (discover) dari sumber informasi yang dominan hanya bersumber dari eksternal petani dan minim dari pengalaman petani (van den Ban \& Hawkins,1999). Berdasarkan hasil penelitian sumber informasi petani kakao sebagian besar dari sesama petani $(43,3 \%)$, penyuluh $(19,8 \%)$, LEMS $(12,7 \%)$ dan sisanya dari dinas, perusahan kakao dan gabungan dari beberapa sumber informasi. Kondisi tersebut menunjukkan bahwa sumber informasi dari petani khususnya petani maju menjadi referensi petani kakao dalam pengembangan kakao di Kolaka Timur. Oleh karena itu, perhatian terhadap pengetahuan petani dari pengalaman yang dimiliki menjadi penting untuk dilihat sebagai suatu pengetahuan. Nonaka dan Takechi (Nawawi, 2012) bahwa tacit knowledge dan explicit knowledge merupakan dua tipe pengetahuan untuk mendapatkan pengetahuan baru sebagai suatu siklus didalam konsep knowledge management. LEMS maupun petani kakao jarang mengakses informasi dari media massa (cetak dan elektronik). Kelembagaan petani dapat memperoleh informasi melalui media internet maupun melakukan komunikasi dengan stakeholder yang terkait dengan kebutuhan petani dalam pengembangan usahataninya (Sumardjo et al., 2011).

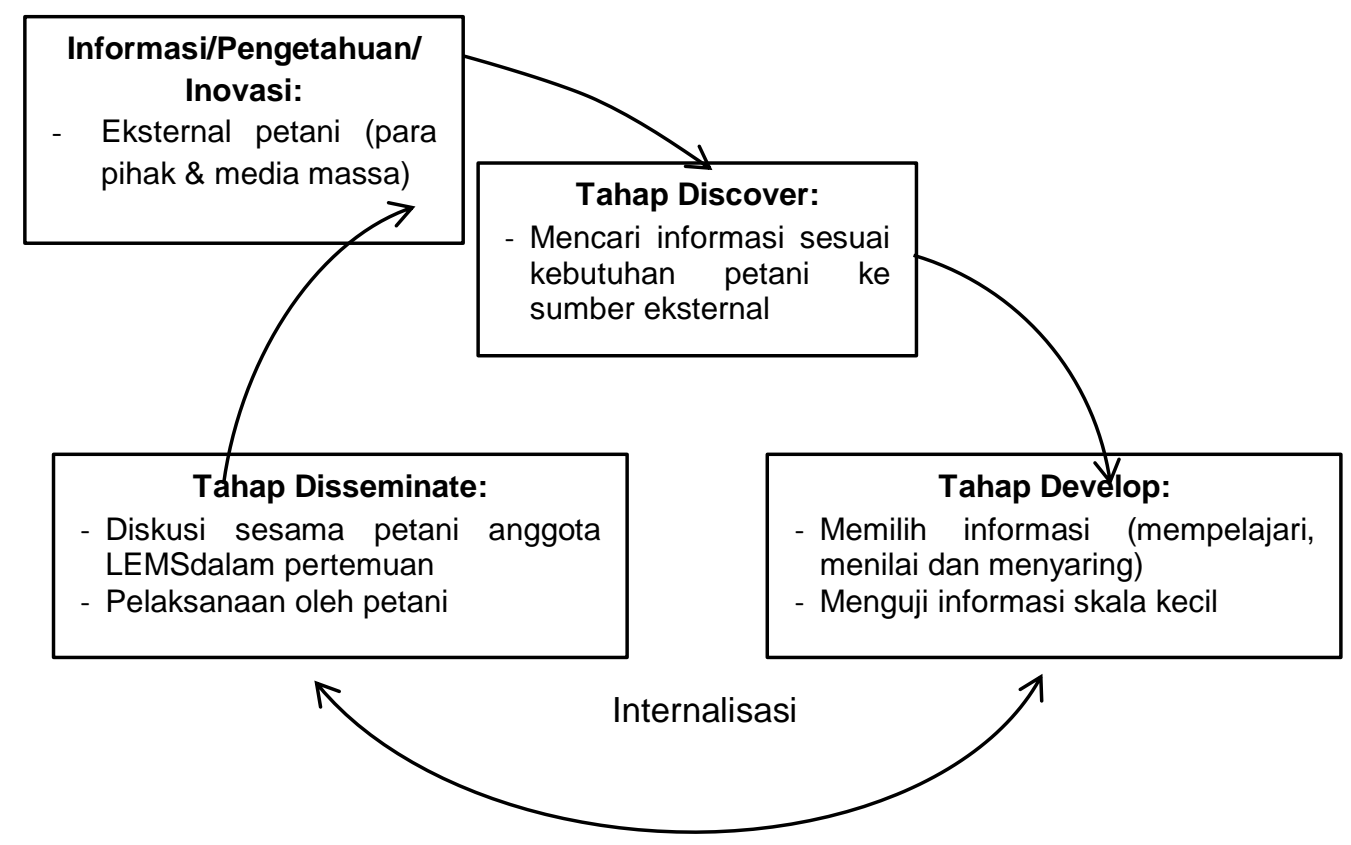

Gambar 6. Proses pengolahan informasi dalam LEMS

Pengelolaan informasi oleh LEMS kurang berjalan baik ini dapat dilihat dari LEMS tidak pernah menyimpan informasi yang diperoleh dalam bentuk soft file/dokumen yang sewaktu-waktu bisa dilihat dan dibaca oleh petani atau siapa saja yang membutuhkan. Kemudian pada tahap develop, LEMS seharusnya dapat berperan sebagai media konsultasi petani terhadap inovasi yang diujikan tersebut. Namun peran ini masih kurang dirasakan oleh petani. Jika proses konsultasi berdasarkan hasil yang diujicobakan berjalan maka akan memunculkan beberapa modifikasi inovasi sesuai dengan kondisi sumberdaya yang ada. Hasil dari modifikasi tersebut menjadi rekomendasi dari LEMS bagi petani lainnya untuk menerapkan inovasi yang sudah diujikan tersebut. Proses tersebut belum sepenuhnya berjalan pada LEMS. Selanjutnya pada tahap disseminate informasi yang diperoleh dalam LEMS disebarkan kepada petani melalui pertemuan LEMS untuk selanjutnya diterapkan oleh petani. Jarang sekali LEMS mengajak petani melakukan kunjungan ke lahan petani yang sudah menerapkan teknologi tersebut, sehingga proses internalisasi kurang berjalan dengan baik. Proses internalisasi akan memungkinkan adanya ide baru terhadap teknologi/inovasi yang ada (Nawawi, 2012).

Proses komunikasi kelembagaan LEMS seharusnya memungkinkan terjadinya knowledge sharing diantara petani maupun lembaga sehingga dapat terjadi komunikasi dua arah dalam proses 
komunikasi dalam kelembagaan petani. Penyampaian pendapat melalui komunikasi dialogis memungkinkan terjadinya proses eksternalisasi, objektivitas dan internalisasi pengetahuan (Husyman \& Wit, 2003). Berjalannya proses komunikasi dalam kelembagaan petani dapat membantu peran penyuluh pertanian dalam penyebaran informasi kepada petani dibalik keterbatasan jumlah penyuluh (Prawiranegara, 2014). Keterbatasan layanan penyuluhan yang diberikan oleh pemerintah kepada petani memungkinkan pendekatan layanan penyuluhan dari petani ke petani maupun dari petani ke kelompok tani menjadi model transpormasi model penyuluhan masa depan (Chand \& Kumar, 2019). Proses pengelolaan informasi melalui agricultural knowledge and information (AKIS) dapat terwujud melalui sinergi berbagai pelaku usaha, jejaring kerja dan lembaga akan dapat menciptakan informasi yang dapat diakses untuk didifusikan dan dimanfaatkan bersama (Mulyandari et al. 2010).

\section{KESIMPULAN}

Pelaksanaan peran komunikasi dalam kelembagaan petani dari lima aspek yang dinilai kategori cukup berperan. Kelimat aspek peran komunikasi perlu ditingkatkan khususnya peran dalam akses informasi dan mediasi informasi dimana kedua peran tersebut yang paling rendah dari kelima peran yang diteliti. Proses pengelolahan informasi oleh kelembagaan LEMS sudah berjalan namun belum sepenuhnya menerapkan prinsip-prinsip knowledge management. Pengelolaan informasi masih dominan bersumber dari explicit knowledge dan kurang mengakomodir pengetahuan dari pengalaman petani (tacit knowledge). Oleh karena itu disarankan kedepan kelembagaan petani (LEMS) dan penentu kebijakan dapat menyeimbangkan sumber informasi atau pengetahuan dalam pengembangan kakao. Tujuannya adalah mengakomodir informasi dan pengetahuan petani sebagai suatu referensi bagi pembuat kebijakan dalam menyusun rekomendasi penerapan paket teknologi kepada petani kakao.

\section{REFERENSI}

Adawiyah, Cut. R., Sumardjo, \& Mulyani, E.S. (2017). Faktor yang Mempengaruhi Peran Komunikasi Kelompok dalam Adopsi Inovasi Teknologi Upaya Khusus (Padi, Jagung, Kedelai) di Jawa Timur, Jurnal Agro Ekonomi. 35 (2): 151-170.

Agunga, A., Cahyono, E.D., Buck, E., \& Scheer, S. (2016). Challenges of Implementing Participatory Extension in Indonesia. The Journal of Communication and Media Research, 8(1), 20-45.

Burton, J.P, Taylor, S.G., Barber, L.K., (2014). Understanding internal, eksternal and relational attributions for abusive supervision, Journal of Organizational Behavior. 35(6):871-891.

Cahyono, E.D. (2014). Challenges Facing Extension Agents in Implementing the Participatory Extension Approach in Indonesia: A Case Study of Malang Regency in the East Java Region. Disertasi. The Ohio State University.

Chand, Atish \& Kumar, Salesh. (2019). Changing Agriculture Extension Models in Pacific Island Countries. Journal of Agricultal Extension. 24 (4). 30-38.

Davis, J., Caskie, P., \& Wallace, M., (2009). Economics of farmer early retirement policy. Journal of Applied Economics. 41(1):35-43.

Dinas Pertanian. (2018). Statistik Pertanian Kabupaten Kolaka Timur. Tirawuta.

Fatchiya, A. (2010). Tingkat Kapasitas Pembudi Daya Ikan dalam Mengelola Usaha Aquakultur secara Berkelanjutan. Jurnal Penyuluhan, 6 (1):11-18.

Fausayana, I., Abdullah, W. G., Susanti, F., Sidu, D., Arimbawa, P., \& Yunus, L. (2017). Factors affecting the behavior of farmers toward the risk of seaweed farming in the Bungin Permai village, southeast Sulawesi, Indonesia. Aquaculture, Aquarium, Conservation \& Legislation, 10(6), 1647-1653.

Figueroa, M.E., Kincaid, D.L., Rani, M., and Lewis, G. (2002). Communication for Social Change: An Integreted Model for Measuring the Process and its Outcomes. The Rockefeller Foundation. New Tork.

Geo, L., \& Saediman, H. (2019). Analysis of Factors Affecting Cocoa Development in Southeast Sulawesi. Pakistan Journal of Nutrition. https://doi.org/10.3923/pjn.2019.479.490.

Gigone, D., \& Hastie, R. (1993). The common knowledge effect: Information sharing and group judgment. Journal of Personality and Social Psychology, 65 (5): 959974. https://doi.org/10.1037/0022-3514.65.5.959

Huysman, M., and Wit, D. (2003). A. Critical Evaluation of Knowledge Management Practices. Sharing Expertise-Beyond Knowledge Management. MIT press. 
Inggrida, J. A., Sukesi, K., \& Cahyono, E. D. (2017). The Role of communication in Mount Kelud eruption disaster management program (Case study in Ngantru Village, Ngantang District, Malang). HABITAT, 28(2), 46-53. https://doi.org/10.21776/ub. habitat.2017.028.2.7

Iriantara, Yosal., (2014). Komunikasi Pembelajaran: Interaksi, Komunikatif dan Edukatif dalam Kelas. Simbiosa Rekatama Media. Bandung.

Jane, O. (2011). Analisis Potensi Partnership Sebagai Modal untuk Meningkatkan Kapabilitas Inovasi dan Teknologi. Jurnal Administrasi Bisnis, 7 (2):192-205.

Kementerian Pertanian Republik Indonesia. (2018). Statistik Pertanian 2018.

Koesoemowardani, N., dan Sumardjo. (2008). Peran Komunikasi dalam Pengembangan Kelembagaan Ketahanan Pangan Masyarakat: Kasus Lumbung Pangan di Ciamis, Jawa Barat, Jurnal Komunikasi Pembangunan. 6 (2): 51-65.

Leeuwis C., (2009). Komunikasi untuk Inovasi Pedesaan: Berpikir Kembali Tentang Penyuluhan Pertanian. Terjemahan: Kanisius. Yogyakarta.

Managanta, A.A., (2018). Kemandirian Petani dalam Meningkatkan Produktivitas Usahatani Kakao di Provinsi Sulawesi Tengah. Disertasi. Sekolah Pascasarjana IPB. Bogor. (https://repository.ipb.ac.id/handle/ 123456789/93841).

Mulyandari, S.R., Sumardjo, N.K. Panjaitan, \& D.P Lubis. (2010). Pola Komunikasi dalam Pengembangan Modal Manusia dan Sosial Pertanian. Forum penelitian agro ekonomi, 28 (2):135-158.

Murphy, G., Hynes, S., Murphy, Donoghue CO, Green S. (2011). Assessing the compatibility of farmland biodiversity and habitats to the specifications of agri environmental schemes using a multinomial logit approach. Journal of Ecologycal Economics. 71(1):111-121.

Nawawi, Ismail., (2012). Manajemen Pengetahuan (Knowledge Management): Teori dan Aplikasi dalam Mewujudkan Daya Saing Organisasi Bisnis dan Publik. Ghalia Indonesia. Bogor.

Nonci, N. (2017). Implementasi Program Gernas Kakao: Studi Kebijakan Program Gernas Kakao di Kabupaten Luwu, Sah Media. Vol 1.

Prawiranegara, D. (2016). Penguatan Peran Kelembagaan Petani dalam Peningkatan Kapabilitas Petani Mengelola Inovasi Berbasis Teknologi Informasi. Disertasi. Sekolah Pascasarjana IPB. Bogor. (https://repository.ipb.ac.id/ handle/123456789/80611).

Rangkuti P.A., (2010). Peran komunikasi dalam Modernisasi Pertaniai Berbasis Koperasi. Jurnal Komunikasi Pembangunan, 08: 42-48.

Rogers, E.M. (2003). Diffusion of Innovations. Fifth Edition. The Free Press. A. Division of Simon and Schuster, Inc. 1230 Avenu of the Americas New York. NY 10020.

Rogers, E. M., \& F.F. Shoemaker. (1987). Communication of Inovation: Memasyarakatkan Ide Ide Baru. Diterjemahkan oleh Abdillah Hanafi. Usaha Nasional. Surabaya.

Rostin, Ernawati, \& Nusantara, A. (2016). Sustainable Study of Primary Comodity Management in South Konawe Indonesia. WSEAS Transactions on Business and Economics, 13: 514-521.

Rusli, S. (2012). Pengantar IImu KependudukanLP3ES. Jakarta.

Shinta, A., Cahyono, E.D. (2007). Verifikasi indikator dan potensi ancaman terhadap ketersediaan benih padi lokal. Jurnal IImu-ilmu Sosial (Social Sciences) 19 (2), 95-104

Sumardjo, Djuara, P.L., Eko, S.M., dan Retno, S.H.M., (2011). Manfaat Sistem Informasi Berbasis Teknologi dan Komunikasi untuk Keberdayaan Petani Sayuran. Informatika Pertaniain, 20 (1):1-13.

Susilowati, S.H., (2016). Fenomena penuaan petani dan berkurangnya tenaga kerja muda serta implikasinya bagi kebijakan pembangunan pertanian, Forum Penelitian Agro Ekonomi. 34 (1): 35-55.

Suprijanto. (2012). Pendidikan Orang Dewasa: Dari Teori Hingga Aplikasi. PT Bumi Aksara. Jakarta.

Widayanto, Y., (2013). Model Perumusan Kebijakan Pendukung Pengembangan Industri Kakao Berbasis Kinerja Driver Rantai Pasok. Disertasi. Sekolah Pascasarjana IPB. Bogor. (https://repository.ipb.ac.id/jspui/bitstream/ 123456789/66688/1/2013ywi.pdf). 